\title{
KETERAMPILAN GURU MENGELOLA KELAS: UPAYA UNTUK MENINGKATKAN PRESTASI BELAJAR SISWA
}

\author{
Armanisah $^{1}$, Tengku Hafinda ${ }^{2}$ \\ Sekolah Tinggi Agama Islam Negeri Tengku Dirundeng Melaboh \\ e-mail: ${ }^{1}$ armanisah21@gmail.com, ${ }^{2}$ tengkuhafinda@staindirundeng.ac.id
}

\begin{abstract}
Abstrak
Penelitian ini bertujuan untuk mengetahui pengaruh keterampilan guru dalam mengelolaan kelas terhadap prestasi belajar IPS siswa kelas IV di MIS Nurul Falah. Penelitian ini menggunakan penelitian kuantitatif data yang terkumpul dalam penelitian ini dapat dianalisis dengan menggunakan analisis statistik. Populasi penelitian siswa kelas IV MIS Nurul Falah sebanyak 42 siswa, yang terbagi menjadi dua yaitu kelas IVA terdiri dari 21 siswa dan kelas IVB terdiri dari 21 siswa. Teknik pengumpulan data yang digunakan dalam penelitian ini adalah statistik dengan menggunakan metode one group pretest dan postest design dengan instrumen penelitian menggunakan tes dan lembar angket. Teknik analisis data yang digunakan adalah statistik deskriptif dengan cara membandingkan nilai rerata prestasi belajar IPS dari kelompok eksperimen dan kontrol. Hasil penelitian menunjukkan bahwa terdapat perbedaan signifikan prestasi belajar IPS antara kelompok eksperimen dan kontrol di mana nilai rerata kelompok eksperimen lebih tinggi daripada kelompok kontrol. Hal ini ditunjukkan dengan nilai rerata pretest dan rerata postest pada kelompok eksperimen yaitu 74,8 dan 82,7 lebih tinggi dibandingkan dengan nilai rerata pretest dan rerata postest kelompok kontrol yaitu 71 dan 72,4. Peningkatan hasil belajar berdasarkan nilai $\mathrm{N}$-Gain kelompok eksperimen lebih tinggi daripada kelompok kontrol pada kategori sedang yaitu 43\% dan 24\%.
\end{abstract}

Kata Kunci: keterampilan guru, mengelola kelas, prestasi belajar

\begin{abstract}
This study aims to determine the effect of teacher skills in classroom management on social studies learning achievement of fourth grade students at MIS Nurul Falah. This study uses quantitative research. The data collected in this study can be analyzed using statistical analysis. The research population of class IV MIS Nurul Falah students was 42 students, which was divided into two, namely class IVA consisting of 21 students and class IVB consisting of 21 students. The data collection technique used in this research is statistics using the one group pretest and posttest design methods with research instruments using tests and questionnaire sheets. The data analysis technique used is descriptive statistics by comparing the average value of social studies learning achievement from the experimental and control groups. The results showed that there was a significant difference in social studies learning achievement between the experimental and control groups where the mean value of the experimental group was higher than the control group. This is indicated by the mean pretest and posttest mean values in the experimental group, which are 74.8
\end{abstract}

Armanisah | Tengku Hafinda | Keterampilan Guru Mengelola Kelas: Upaya Untuk Meningkatkan Prestasi Belajar Siswa | 167 
and 82.7, which are higher than the mean pretest and posttest mean values in the control group, namely 71 and 72.4. The increase in learning outcomes based on the $\mathrm{N}$-Gain value of the experimental group was higher than the control group in the medium category, namely $43 \%$ and $24 \%$, respectively.

Keywords: teacher skills, class management, learning achievement

\section{PENDAHULUAN}

Mendidik merupakan suatu aktifitas yang memiliki tujuan yang hendak dicapai. Dalam suatu sistem pendidikan, mendidik berada dalam suatu proses yang berkesinambungan pada setiap jenis dan jenjang pendidikan. Tugas guru dalam menyampaikan materi pelajaran hendaknya mampu menciptakan suasana kelas yang menyenangkan. Suasana kelas yang menyenangkan mampu memberi semangat kepada siswa untuk belajar. Guru tidak sekedar menyampaikan materi pelajaran kepada siswa, tetapi juga bagaimana menyiapkan mereka menjadi manusia yang terampil dan siap menghadapi tantangan global yang terjadi di masa depan. Seorang guru hendaknya mampu mengarahkan dan membimbing siswa untuk aktif dalam kegiatan belajar mengajar, sehingga tercipta suasana serta interaksi yang baik antara guru dengan siswa maupun siswa dengan siswa. Keaktifan serta terjadinya perubahan perilaku yang selaras dengan tujuan pengajaran yang hendak dicapai merupakan suatu hal yang menandai terjadinya proses pembelajaran. Selain itu, guru menjadi faktor yang berpengaruh terhadap hasil belajar siswa di sekolah hendaknya menguasai keterampilan mengajar dan menerapkannya dalam proses belajar mengajar. Salah satu keterampilan yang harus dimiliki guru adalah keterampilan mengelola kelas mengingat tugas guru di dalam kelas adalah membelajarkan siswa dengan menyediakan kondisi belajar yang optimal,dan sesuai tujuan pengajaran yang hendak dicapai.

Menurut Sri Anitah Wiryaman \& Noorhadi menyatakan bahwa pengelolaan kelas merupakan suatu kegiatan pengaturan siswa dan pengaturan fisik kelas sehingga kegiatan pembelajaran dapat berjalan dengan lancar atau terciptanya suasana belajar yang optimal bagi berlangsungnya kegiatan belajar siswa yang efektif (Wiryawan and Noorhadi 2001). Pengelolaan kelas merupakan salah satu keterampilan guru dalam menciptakan dan memelihara kondisi belajar yang optimal dan mengembalikannya bila terjadi gangguan dalam proses belajar mengajar. Maksud dari gangguan selama proses pembelajaran yaitu siswa yang gaduh selama pembelajaran berlangsung, siswa mengganggu siswa yang lain, mengantuk saat mengikuti pembelajaran. Guru yang berperan sebagai pengelola kelas, hendaknya dapat menyediakan fasilitas yang memungkinkan kemudahan kegiatan belajar siswa, dan 
lingkungan belajar yang menyenangkan siswa sehingga siswa dapat mengikuti kegiatan belajar mengajar dengan aman dan nyaman.

Pengelolaaan kelas yang dilakukan oleh guru diharapkan dapat menciptakan kondisi kelas yang menunjang proses pembelajaran. Kondisi kelas yang diharapkan mencakup lingkungan, emosional, intelektual serta sosial di dalam kelas. Keberhasilan guru dalam mengajar di kelas bukan hanya ditentukan dari pengetahuan tentang kurikulum, metode mengajar, media pengajaran, dan wawasan tentang materi yang akan disampaikan kepada anak didik, tetapi guru juga harus menguasai cara mengelola kelas. Pengelolaan kelas memiliki peranan penting dalam keberhasilan proses pembelajaran dimana guru mampu menciptakan suasana belajar yang aktif, kreatif dan menyenangkan. Djamarah menyatakan bahwa suatu kondisi belajar yang optimal dapat dicapai dengan cara mengatur anak didik dan sarana pengajaran serta mengendalikannya dalam suasana yang menyenangkan guna mencapai tujuan pengajaran(Djamarah 2002). Dengan adanya pengelolaan kelas diharapkan mampu menjadikan kondisi belajar yang optimal serta suasana kelas yang menyenangkan selama proses pembelajaran berlangsung.

Untuk memperoleh kegiatan belajar mengajar yang optimal, maka diperlukan pengelolaan kelas yang efektif. Pengelolaan kelas yang efektif akan menghasilkan pengajaran yang efektif pula. Untuk menciptakan pengajaran yang efektif dapat dilakukan dengan melakukan kegiatan-kegiatan yang dapat menciptakan serta mengkondisikan kelas yang optimal bagi terjadinya proses belajar mengajar, antara lain: penghentian tingkah laku siswa yang mengganggu perhatian kelas, pemberian penghargaan kepada siswa yang menyelesaikan tugas dengan tepat waktu, hubungan/interaksi yang baik antar guru dengan siswa maupun siswa dengan siswa, dan mampu mengatur siswa serta mengendalikannya sehingga tercipta suasana yang menyenangkan selama proses pembelajaran berlangsung. Prestasi yang diperoleh siswa dalam mengikuti proses pembelajaran di kelas merupakan salah satu tolak ukur keberhasilan siswa di sekolah. Prestasi belajar yang dimaksud adalah tingkat pencapaian hasil yang telah dicapai siswa berupa pengetahuan, pemahaman dan penerapan. Jadi dapat dikatakan bahwa prestasi siswa merupakan hasil belajar siswa yang diperoleh selama proses kegiatan belajar mengajar.

Berdasarkan preobservasi yang dilakukan di MIS Nurul Falah, peneliti mengamati pengelolaan kelas yang dilakukan oleh guru belum dilakukan secara maksimal. Ketika kegiatan belajar mengajar berlangsung, guru masih melaksanakan pembelajaran dengan suasana kelas yang monoton dengan kata lain selalu sama, berulang-ulang atau tidak ada perubahan dalam proses belajar mengajar, belum ada variasi dalam kegiatan belajar Armanisah | Tengku Hafinda | Keterampilan Guru Mengelola Kelas: Upaya Untuk Meningkatkan Prestasi 
mengajar. Ketika kegiatan belajar mengajar berlangsung sudah ada kontrol dari guru, hanya saja lebih terfokus pada pengaturan siswa berupa tindakan korektif, sedangkan pengelolaan fisik belum dilakukan, misal guru tidak membuka jendela agar terjadi sirkulasi udara yang baik. Jika ada siswa yang berjalan-jalan di kelas saat pembelajaran berlangsung, guru tidak langsung memberikan tindakan berupa teguran pada siswa. Kelas yang gaduh akan mempengaruhi konsentrasi siswa dalam mengikuti pembelajaran. Guru harus lebih tanggap terhadap situasi serta kondisi di kelas agar suasana kelas yang kondusif tetap terjaga. Selain sikap tanggap seorang guru terhadap situasi di kelas, guru juga harus mampu membagi perhatian pada saat dilakukan kegiatan yang berlangsung pada waktu yang sama (tidak terfokus pada satu siswa/kelompok).

Fasilitas yang tersedia di sekolah tidak digunakan dalam proses pembelajaran. Sekolah memiliki beranekaragam alat KIT atau media pembelajaran yang dapat digunakan selama proses kegiatan belajar mengajar. Siswa akan lebih antusias mengikuti pembelajaran dengan penggunaan media yang menarik dan menyenangkan. Dengan begitu siswa akan lebih bersemangat dan fokus dalam proses pembelajaran, hal ini akan memudahkan guru dalam melakukan pengelolaan kelas. Sejalan dengan penggunaan fasilitas di sekolah merupakan salah satu pengelolaan kelas secara fisik, yaitu berupa alat pengajaran. Guru memerlukan adanya perbaikan dalam penerapan pengelolaan kelas baik secara fisik maupun pengaturan siswa. Penelitian yang dilakukan di MIS Nurul Falah untuk siswa kelas IV yang terdiri atas kelas IVA dan kelas IVB. Peneliti menggunakan kedua kelas tersebut untuk pengambilan data. Kelompok eksperimen merupakan kelas yang diberi perlakuan pengelolaan kelas secara fisik dan pengaturan siswa, sedangkan kelompok kontrol merupakan kelas yang diberi perlakuan pengelolaan kelas berupa pengaturan siswa. Menurut Syaiful Bahri Djamarah yang termasuk dalam pengelolaan kelas secara fisik dapat dilakukan dengan membuka jendela agar udara segar dapat masuk ke ruangan atau agar ruangan menjadi terang, menyalakan lampu listrik, menggeser papan tulis maupun mengatur meja. Dengan begitu, peneliti melakukan pengelolaan kelas secara fisik dengan cara: mengatur tempat duduk siswa, menata ruangan kelas, mengatur waktu dan media pembelajaran, dan penciptaan disiplin kelas(Djamarah 2002). Untuk pengaturan siswa berupa tindakan pencegahan/preventif dan tindakan korektif. Sedangkan kelompok kontrol merupakan kelas yang diberi perlakuan pengelolaan kelas berupa pengaturan siswa. Guru melaksanakan proses pembelajaran dengan penerapan pengelolaan kelas yang biasa dilakukan selama pembelajaran sebelumnya (biasa dilakukan sehari-hari).

Armanisah | Tengku Hafinda | Keterampilan Guru Mengelola Kelas: Upaya Untuk Meningkatkan Prestasi Belajar Siswa | 170 
Ditinjau berdasarkan hasil pra penelitian, hasil ujian siswa MIN Nurul Falah belum memenuhi Kriteria Ketuntasan Minimal (KKM) pada mata pelajaran IPS. Pada tingkat mata pelajaran Ilmu Pengetahuan Sosial mengacu pada pembelajaran terpadu (integrated). Mata pelajaran IPS tidak diajarkan secara terpisah melainkan dengan cara menggabungkan beberapa disiplin ilmu yang saling terkait. Menurut Sapriya dokumen Permendiknas IPS merupakan mata pelajaran yang mengkaji seperangkat peristiwa, fakta, konsep, dangeneralisasi yang berkaitan dengan isu sosial(Sapriya 2009). Selain itu, Menurut Etin Solihatin menyatakan bahwa mempelajari IPS dapat memberi bekal kemampuan dasar kepada siswa untuk mengembangkan diri sesuai dengan bakat, minat, kemampuan dan lingkungannya, serta digunakan untuk melanjutkan ke jenjang pendidikan yang lebih tinggi(Solihatin 2009).

Mata pelajaran IPS kelas IV terdiri atas materi yang berupa kegiatan yang terjadi di lingkungan sekitar siswa. Saat pelajaran IPS berlangsung, siswa lebih sering mempelajari materi dari buku pegangan siswa. Pada mata pelajaran IPS siswa mempelajari materi dengan cara menghafal. Hal ini dikarenakan pada mata pelajaran IPS materinya berupa banyak konsep-konsep dalam lingkungan sekitar masyarakat. Hanya saja cara penyampaian materi dan penciptaan suasana kelas yang kurang menyenangkan maupun pengelolaan kelas yang belum maksimal mengakibatkan nilai rata-rata kelas IVA dan IVB pada mata pelajaran IPS kurang optimal. Mata pelajaran IPS akan lebih mudah dipahami oleh siswa jika menggunakan media pembelajaran yang lebih nyata dan sering dilihat maupun didengar oleh siswa(Hizam 2015; S. Eko Putro Widoyoko 2008). Selain media yang digunakan, pengaturan tempat duduk siswa serta berbagai tindakan yang dilakukan selama proses pembelajaran berlangsung juga mempengaruhi tingkat pemahaman siswa. Berdasarkan hal yang dilakukan oleh guru tersebut merupakan salah satu kegiatan yang dilakukan dalam mengelola kelas dan digunakan sebagai solusi atas permasalahan yang ada di kelas. Penelitian mengenai pengaruh kerampilan guru dalam mengelola kelas telah banyak dilakukan seperti penelitian yang dilakukan oleh Pratiwi menunjukkan bahwa ada pengaruh yang signifikan antara keterampilan guru dalam pengelolaan kelas terhadap prestasi belajar ips siswa kelas IV di Madrasah Ibtidaiyah(MI) 1 Lampung Timur, ini dapat dilihat dari hasil perhitungan analisis Pearson Product Moment yang kemudian dihitung dengan uji tes(Pratiwi 2018).

Suasana yang kurang kondusif juga terlihat dari adanya sebagian siswa yang mengantuk dan mengganggu siswa yang lain saat proses kegiatan belajar mengajar berlangsung. Kurangnya interaksi yang terjadi antar guru dengan siswa, juga mempengaruhi keterlibatan serta antusias siswa dalam mengikuti pelajaran. Situasi tersebut terjadi karena siswa merasa Armanisah | Tengku Hafinda | Keterampilan Guru Mengelola Kelas: Upaya Untuk Meningkatkan Prestasi Belajar Siswa $\mid 171$ 
bosan dan tidak memiliki ketertarikan untuk mengikuti pelajaran dengan baik dan bersemangat. Berdasarkan uraian di atas, maka peneliti tertarik untuk mengetahui pengaruh pengelolaan kelas terhadap prestasi belajar IPS siswa.

\section{KAJIAN TEORETIS}

Menurut Arikunto pengelolaan kelas adalah suatu usaha yang dilakukan oleh penanggung jawab kegiatan belajar mengajar atau membantu dengan maksud agar dicapai kondisi optimal sehingga dapat terlaksana kegiatan belajar seperti yang diharapkan. Penanggung jawab kegiatan belajar mengajar yang dimaksud adalah guru(Arikunto 2007). Untuk tercapainya tujuan pembelajaran perlu adanya tindakan yang dapat mewujudkan terciptanya suasana kelas yang optimal. Pengelolaan kelas dilihat dari dua segi yaitu pengelolaan yang menyangkut siswa (pengaturan siswa) dan pengelolaan secara fisik. Pengelolaan fisik yang berupa ruangan, perabot serta alat pelajaran. Djamarah menyatakan bahwa pengelolaan kelas dilakukan untuk menciptakan lingkungan belajar yang kondusif bagi siswa sehingga tercapai tujuan pembelajaran yang efektif dan efisien. Penciptaan lingkungan belajar dapat dilakukan dengan menata kondisi kelas agar siswa lebih antusias dalam mengikuti pembelajaran. Penataan kelas termasuk dalam pengelolaan kelas secara fisik(Djamarah 2002).

Pengelolaan kelas secara fisik berupa pengaturan ruang kelas yang meliputi pengaturan tempat duduk, pengaturan alat-alat pengajaran, penataan keindahan dan kebersihan kelas serta ventilasi dan tata cahaya. Pengelolaan kelas dengan pengaturan siswa dilakukan apabila adanya gangguan di kelas dan guru berusaha untuk mengembalikannya sehingga suasana kelas tetap kondusif. Menurut Entang \& Joni dilakukan selama proses pembelajaran berlangsung. Pengaturan siswa tersebut dilakukan dengan dua langkah yaitu: Tindakan pencegahan/preventif dan Tindakan korektif. Tindakan preventif/pencegahan merupakan suatu tindakan yang dilakukan guru sebelum melakukan kegiatan pembelajaran, misalnya dengan mengajak siswa untuk tetap terkondisikan selama proses pembelajaran berlangsung. Sedangkan tindakan korektif merupakan tindakan yang dilakukan guru terhadap tingkah laku siswa yang dapat mengganggu proses pembelajaran yang sedang berlangsung(Entang and Joni 2001). Tindakan ini dilakukan guru dengan pemberian teguran sampai pemberian sanksi kepada siswa yang membuat gaduh selama proses pembelajaran berlangsung sehingga kondisi belajar dapat kembali kondusif.

Pengelolaan kelas memiliki peranan penting dalam keberhasilan proses pembelajaran dimana guru mampu menciptakan suasana belajar yang aktif, kreatif dan menyenangkan. 
Menurut Syaiful Bahri Djamarah menyatakan bahwa suatu kondisi belajar yang optimal dapat dicapai dengan cara mengatur anak didik dan sarana pengajaran serta mengendalikannya dalam suasana yang menyenangkan guna mencapai tujuan pengajaran. Dengan adanya pengelolaan kelas diharapkan mampu menjadikan kondisi belajar yang optimal serta suasana kelas yang menyenangkan selama proses pembelajaran berlangsung. Menurut Kadir pengelolaan kelas merupakan prasyarat mutlak bagi terjadinya proses pembelajaran yang efektif dengan cara menciptakan situasi yang kondusif. Suatu kondisi belajar yang kondusif dapat tercapai jika guru mengatur peserta didik dan sarana pengajaran serta mengendalikannya dalam suasana yang menyenangkan untuk mencapai tujuan pengajaran, serta hubungan interpersonal yang baik antara guru dan peserta didik, peserta didik dengan peserta didik(Kadir 2006). Menurut Semiawan guru adalah pembimbing dan pengarah yang mengemudikan perahu tetapi tenaga untuk menggerakkan perahu tersebut haruslah berasal dari mereka atau peserta didik yang belajar. Perahu disini diibaratkan sebagai seorang siswa. Pembelajaran merupakan suatu proses yang kompleks dan melibatkan berbagai aspek yang saling berkaitan. Oleh karena itu, untuk menciptakan pembelajaran yang kreatif, dan menyenangkan, diperlukan berbagai keterampilan. Diantaranya adalah keterampilan membelajarkan atau keterampilan mengajar(Semiawan, Conny. 1992). Keterampilan mengajar merupakan kompetensi profesional yang cukup komplek, sebagai integrasi dari berbagai kompetensi guru secara utuh dan menyeluruh.

Menurut Arikunto manajemen atau pengelolaan dalam pengertian umum adalah pengadministrasian, pengaturan atau penataan suatu kegiatan. Pelaksanaan pengelolaan kelas dilakukan dengan metode atau pendekatan pendekatan dan prinsip pengelolaan kelas,sehingga pelaksanaan pengelolaan kelas dapat berjalan dengan lancar. Guru harus mampu menampilkan sikap professional, lewes, bersemangat dan disipiln yang tinggi. Proses pengelolaan kelas penting untuk diketahui oleh siapapun terutama seorang guru yang mengabdikan dirinya kedalam dunia pendidikan. Kegiatan manajemen atau pengelolaan kelas dapat diartikan sebagai kemampuan guru atau wali kelas dalam mendayagunakan potensi kelas berupa pemberian kesempatan yang seluas-luasnya pada setiap personal untuk melakukan kegiatan-kegiatan yang kreatif dan terarah sehingga waktu dan dana yang tersedia dapat dimanfaatkan secara efisien untuk melakukan kegiatan-kegiatan kelas yang berkaitan dengan kurikulum dan perkembangan siswa. Secara umum pengelolaan kelas adalah penyedian fasilitas bagi bermacam macam kegiatan belajar siswa dalam lingkungan sosial, emosional, dalam intelektual dalam kelas. Fasilitas yang demikian itu memungkinkan siwa belajar dan bekerja, terciptanya suasana sosial yang memberikan kepuasan, suasana disiplin, Armanisah | Tengku Hafinda | Keterampilan Guru Mengelola Kelas: Upaya Untuk Meningkatkan Prestasi Belajar Siswa | 173 
perkembangan intelektual, emosional dan sikap serta apresiasi pada siswa dalam proses pembelajaran dilingkup satuan pendidikan. Tujuan pengelolaan kelas pada hakikatnya telah terkandung dalam tujuan pendidikan. Secara umum pengelolaan kelas adalah penyedian fasilitas bagi bermacam macam kegiatan belajar siswa dalam lingkungan sosial, emosional, dalam intelektual dalam kelas. Fasilitas yang demikian itu memungkinkan siwa belajar dan bekerja, terciptanya suasana sosial yang memberikan kepuasan, suasana disiplin, perkembangan intelektual, emosional dan sikap serta apresiasi pada siswa.

\section{METODE}

Penelitian ini merupakan jenis penelitian kuantitatif. Penelitian kuantitatif suatu usaha yang sistematis dan objektif untuk mencari pengetahuan yang dapat dipercaya dan juga cara ilmiah untuk mendapatkan data dengan tujuan dan kegunaan tertentu disebut dengan kuantitatif karena data data yang terkumpul dalam penelitian ini dapat dianalisis dengan menggunakan analisis statistik. Jadi menurut peneliti penelitian kuantitatif yaitu suatu penelitian yang datanya berupa angka yang digunakan sebagai alat untuk menemukan sebuah keterangan. Creswell menyatakan bahwa penelitian kuantitatif merupakan penelitian yang bekerja dengan angka, yang datanya berwujud bilangan (skor atau nilai, peringkat atau frekuensi), yang dianalisis dengan menggunakan statistik untuk menjawab pertanyaan atau hipotesis penelitian yang spesifik, dan untuk melakukan prediksi bahwa suatu variabel tertentu mempengaruhi variabel yang lain(Creswell 2003).

Desain penelitian adalah rencana tentang cara mengumpulkan dan menganalisis data agar dapat dilaksanakan secara ekonomis serta serasi dengan tujuan penelitian Nasution. Penelitian yang digunakan untuk mencari pengaruh perlakuan tertentu terhadap yang lain dalam kondisi yang terkendalikan dinamakan penelitian eksperimen Sugiyono. Dalam penelitian ini menggunakan metode penelitian eksperimen kuasi (quasi experimental design) dengan desain nonequivalen control group design. Penelitian eksperimen kuasi merupakan suatu jenis penelitian eksperimen yang kelompok kontrolnya tidak berfungsi sepenuhnya untuk mengontrol variabel-variabel luar yang mempengaruhi pelaksanaan eksperimen(Sugiyono 2011). Adapun desain penelitian ini adalah sebagai berikut:

Tabel desain penelitian

\begin{tabular}{|c|c|c|c|}
\hline Kelompok & Pretest & Perlakuan & Posttest \\
\hline E & $\mathbf{0}_{1}$ & X & $\mathbf{0}_{2}$ \\
\hline K & $\mathbf{0}_{3}$ & - & $\mathbf{0}_{4}$ \\
\hline
\end{tabular}

Keterangan :

E : Kelas Eksperimen

Armanisah | Tengku Hafinda | Keterampilan Guru Mengelola Kelas: Upaya Untuk Meningkatkan Prestasi Belajar Siswa | 174 


\section{$\mathrm{K}:$ Kelas Kontrol}

$\mathrm{X}$ : Perlakuan pengelolaan kelas secara fisik dan pengaturan siswa

- : Perlakuan pengelolaan kelas berupa pengaturan siswa

$\mathrm{O}_{1}$ : Pretest kelas eksperimen

$\mathrm{O}_{2}:$ Posttest kelas eksperimen

$\mathrm{O}_{3}$ : Pretest kelas kontrol

$\mathrm{O}_{4}:$ Posttest kelas kontrol

Variabel Penelitian

Menurut Suharsimi Arikunto, terdapat dua variabel yang dipengaruhi oleh suatu treatment, yaitu variabel bebas atau independent variable $(\mathrm{X})$ dan variabel terikat atau dependent variable (Y). Variabel bebas merupakan variabel yang diselidiki pengaruhnya terhadap gejala atau permasalahan yang ada, sedangkan variabel terikat merupakan suatu variabel yang akan muncul sebagai pengaruh dari variabel bebas. Berkaitan dengan pendapat tersebut, pada penelitian ini terdapat dua variabel, yaitu: variabel bebas (independent variabel) adalah pengelolaan kelas, dan variabel terikat (dependent variabel) adalah prestasi belajar IPS. Berikut penjelasan tentang definisi operasional variabel:

1. Variabel bebas (pengelolaan kelas) yaitu:

a. Pada kelompok eksperimen diberikan pengelolaan kelas secara fisik dan pengaturan siswa. Pengelolaan kelas secara fisik meliputi pengaturan tempat duduk (meliputi aspek postur tubuh siswa/tinggi rendahnya siswa, siswa yng memiliki gangguan penglihatan maupun pendengaran), penataan ruang kelas, mengatur waktu dan media pembelajaran serta penciptaan disiplin kelas, sedangkan untuk pengaturan siswa dilakukan dengan tindakan preventif dan tindakan korektif. Tindakan preventif dilakukan sebelum memulai kegiatan pembelajaran, misalnya guru memberikan penjelasan agar siswa tetap terkondisikan selama mengikuti pembelajaran, sedangkan tindakan korektif diberikan apabila telah terjadi gangguan dalam proses belajar mengajar. misalnya guru langsung memberikan teguran pada siswa yang berbicara sendiri saat guru sedang menjelaskan materi pelajaran.

b. Pada kelompok kontrol diberikan pengelolaan kelas berupa pengaturan siswa, dimana guru melaksanakan proses pembelajaran dengan penerapan pengelolaan kelas yang biasa dilakukan selama pembelajaran sebelumnya (biasa dilakukan sehari-hari).

2. Variabel terikat (prestasi belajar IPS), yaitu:

Prestasi belajar IPS merupakan tingkat pencapaian hasil yang telah dicapai siswa berupa pengetahuan, pemahaman dan penerapan. Untuk memperoleh data prestasi belajar IPS dengan cara memberikan soal pretest dan posttest pada kelompok eksperimen dan kelompok kontrol dengan soal yang sama. 
Teknik pengumpulan data adalah cara yang dilakukan oleh peneliti untuk mengumpulkan data. Dalam penelitian ini teknik pengumpulan data yang digunakan adalah tes dan observasi. Tes digunakan untuk mengukur prestasi belajar IPS yaitu dengan memberikan pretest (sebelum diberi perlakuan) dan posttest (setelah diberi perlakuan) pada kelompok eksperimen dan kelompok kontrol. Tes yang digunakan pada kelompok kontrol dan eksperimen dibuat sama, baik dari segi jumlah soal maupun tingkat kesulitannya.

Instrumen Penelitian Instrumen yang digunakan dalam penelitian ini adalah dengan menggunakan instrumen tes dan angket respon siswa. Soal tes disusun oleh peneliti dengan jumlah 20 soal dalam bentuk pilihan ganda dengan 4 pilihan jawaban. Instrumen ini digunakan untuk soal pretest dan soal posttest. Instrumen penelitian yang telah dibuat segera dilakukan uji coba pada siswa untuk menguji validitas dan reliabilitas instrumen uji instrumen dilakukan pada siswa kelas IV MIS Nurul Falah.

Teknik Analisis Data Teknik analisis data pada penelitian ini menggunakan teknik statistik deskriptif dengan jenis pemusatan data dengan mencari nilai rerata (mean) dengan formula sebagai berikut:

Ket:

$$
\bar{X}=\frac{\sum f i \cdot x i}{\sum f i}
$$

$\bar{X} \quad=$ Nilai rerata

$\mathrm{Fi} \quad=$ Frekuensi kelompok data ke-i

$\mathrm{Xi}=$ Nilai tengah kelompok data ke-i

Hal ini dikarenakan pada penelitian ini menggunakan penelitian populasi. Sugiyono menyatakan untuk penghitungan statistik menggunakan pemusatan data diperoleh dari nilai rerata (mean) populasi posttest kelompok kontrol dan kelompok eksperimen(Sugiyono 2011). Untuk hasil nilai preetest dan postest akan dicari peningkatan prestasi hasil belajar siswa denga menggunakan rumus menurut Gain

(g),dengan formula sebagai berikut:

Ket:

$$
(g)=\frac{(\text { S post })-(\text { S pre })}{100 \%-(\text { S pre })}
$$

(g) $\quad=$ Nilai yang dicari

$(S$ post $) \quad=$ Nilai rata-rata postest

$(S$ pre $) \quad=$ Nilai rata-rata pretest

Selanjutnya setelah dihitung peningkatan (N-Gain) dengan menggunakan rumus di atas, dibuat atau diklasifikasi dengan criteria sebagai berikut: 


Tabel Kategori peningkatan hasil prestasi siswa (N-gain)
\begin{tabular}{|c|c|}
\hline Nilai Gain & Kategori \\
\hline $0,00-0,29$ & Rendah \\
\hline $0,30-0,69$ & Sedang \\
\hline $0,70-1,00$ & Tinggi \\
\hline
\end{tabular}

\section{HASIL DAN PEMBAHASAN}

Penelitian ini dilaksanakan pada kelas IV di Mis Nurul Falah. Kelas IV di Mis Nurul Falah terdiri dari dua kelas pararel, yaitu IVA dan IVB. Kelas IVA terdiri dari 21 siswa, dan kelompok eksperimen terdiri dari 21 siswa. Penelitian ini merupakan penelitian populasi, karena menggunakan seluruh siswa kelas IVA dan IVB, sehingga disebut subjek penelitian. Masing-masing kelas diberikan pretest dan posttest dengan soal tes yang sama, baik dari jumlah soal maupun tingkat kesulitannya.

Pada pelaksanaan penelitian ini, jumlah waktu pembelajaran yang diberikan pada kelompok eksperimen dan kelompok kontrol sama yaitu 2 jam pelajaran, dengan waktu pelajaran pada jam pertama pukul 08.00-09.40. Pelaksanaan penelitian ini adalah pada bulan April 2021. Pelaksanaan pretest pada kelompok eksperimen dilaksanakan tanggal 14 April 2021 dan kelompok kontrol pada tanggal 20 April 2021, sedangkan post-test pada kelompok eksperimen dilaksanakan tanggal 19 April 2021 dan kelompok kontrol pada tanggal 242021. Selain jumlah waktu pembelajaran yang sama, materi pelajaran yang disampaikan pada kelompok eksperimen dan kelompok kontrol juga sama yaitu perkembangan teknologi produksi, komunikasi dan transportasi serta pengalaman menggunakannya.

Hasil penelitian pada kelompok kontrol yang diberi pengelolaan kelas berupa pengaturan siswa memperoleh nilai rerata yang awalnya 71 menjadi 72,4 hal tersebut berarti terjadi kenaikan sebesar 1,4\% dan nilai N-Gain mendapatkan prestasi siswa sebesar, sedang $23 \%$ dan rendah $76, \%$. Hasil yang berbeda ditunjukkan oleh kelompok eksperimen yang diberi pengelolaan kelas secara fisik dan pengaturan siswa menunjukkan hasil yang lebih baik, di mana nilai rerata yang awalnya 74,8 menjadi 82,7 hal tersebut terjadi kenaikan 9,5\% dan nilai N-Gain terdapat nilai sebesar, sedang $42 \%$ dan rendah $57 \%$.

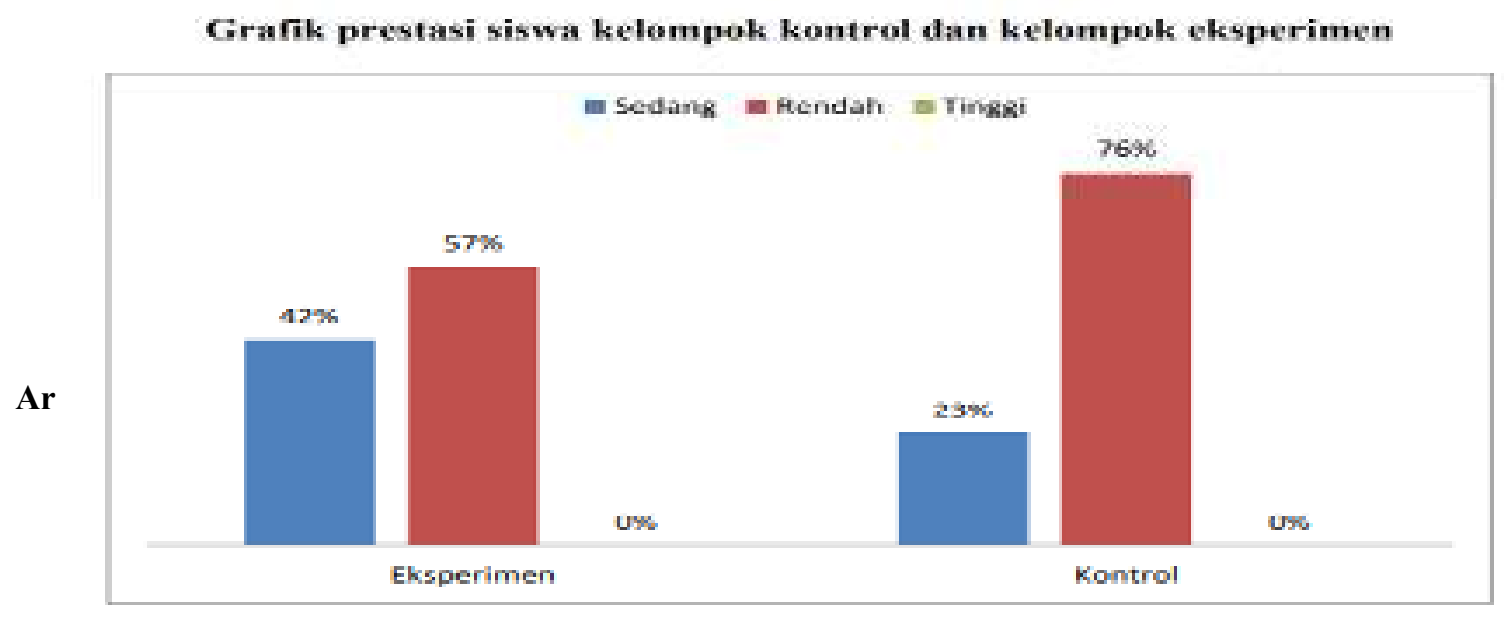


Prestasi belajar IPS siswa kelas IV yang diperoleh kelompok IVB yang diberi perlakuan pengelolaan kelas secara fisik dan pengaturan siswa dan kelompok IVA yang diberi perlakuan pengelolaan kelas berupa pengaturan siswa menunjukkan adanya perbedaan. Hal ini ditunjukkan dengan perbedaan nilai rerata antara kelompok eksperimen dan kelompok kontrol sebesar 82,7 dilihat dari selisih nilai rerata posttest. Berdasarkan hasil tersebut, jika pengelolaan kelas diterapkan secara efektif dan optimal, maka semakin baik pula prestasi belajar siswa. Sehingga pengelolaan kelas berpengaruh terhadap prestasi belajar IPS siswa kelas IV Mis Nurul Falah.

Berdasarkan hasil penelitian dari lembar observasi, menunjukkan bahwa terdapat beberapa faktor yang mempengaruhi pencapaian prestasi belajar IPS siswa diantaranya penataan tempat duduk siswa dalam kelas, penataan ruang, dan penggunaan alat peraga dalam pengajaran serta penciptaan disiplin kelas, strategi pembelajaran. Data tentang variabel respon siswa mengenai perubahan dalam proses belajar mengar berpengaruh terhadap prestasi belajar siswa kelas IV di Mis Nurul Falah yang berhasil dikumpulkan dari responden sebanyak 21 siswa.

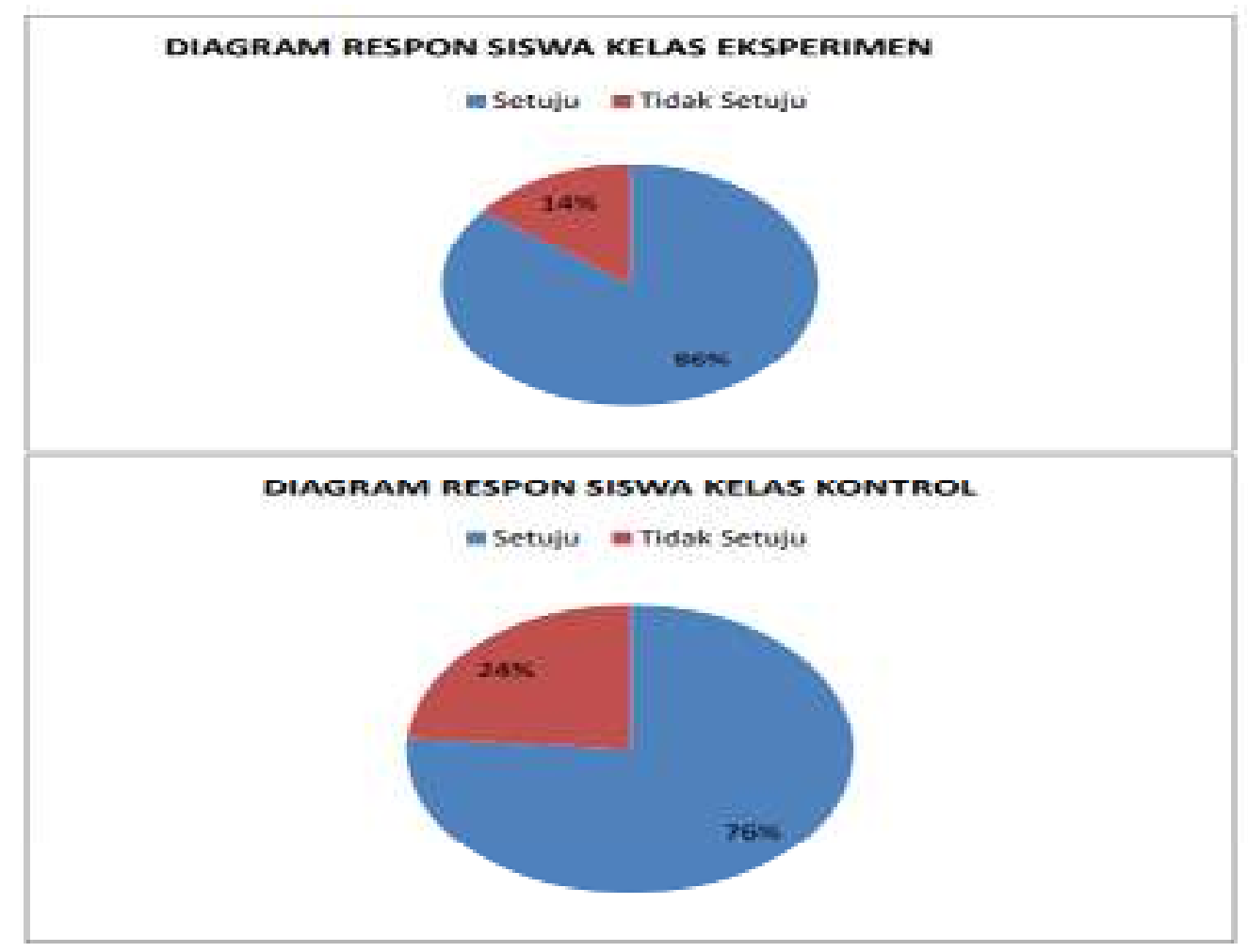

Berbagai hal yang telah disebutkan di atas memiliki karakteristik yang sama, yaitu pengelolaan kelas merupakan sebuah upaya nyata yang dilakukan untuk mewujudkan suatu kondisi proses atau kegiatan belajar mengajar yang efektif. Dengan pengelolaan kelas yang efektif dan optimal dapat mendukung terciptanya suasana kelas yang baik guna tercapainya 
tujuan pembelajaran. Hal ini didukung dengan pendapat dari penelitian Husaini Usman yang menyatakan bahwa untuk menunjang tingginya penciptaan iklim kelas yang kondusif, maka harus ditunjang pula dengan fasilitas yang menyenangkan, seperti : sarana prasarana, pengaturan lingkungan kelas, pengaturan lingkungan sekolah, penampilan dan sikap guru, serta hubungan yang harmonis baik antara guru dengan siswa dan antara siswa itu sendiri(Usman and Akbar 2011). Pada kelompok eksperimen, penerapan pengelolaan kelas dilakukan secara fisik dan pengaturan siswa. Pengelolaan kelas secara fisik dilakukan dengan mengatur tempat duduk siswa, menata ruangan kelas, mengatur waktu dan media pembelajaran, dan penciptaan disiplin kelas. Pengelolaan kelas dengan pengaturan siswa dilakukan dengan pemberian tindakan preventif dan tindakan korektif.

Penerapan pengelolaan kelas secara fisik dilakukan dengan mengatur tempat duduk siswa. Tempat duduk siswa diatur dengan bentuk yang bervariasi. Posisi duduk tersebut membantu siswa untuk melihat media pembelajaran dengan lebih jelas serta lebih mudah dalam memahami materi pelajaran yang disampaikan oleh guru. Selanjutnya menata ruangan kelas, ruang kelas ditata dengan memberikan dekorasi pada dinding kelas dengan gambar yang membantu dalam pemahaman materi. Membuka jendela sebagai ventilasi ruangan agar terjadi proses sirkulasi udara yang baik. Ruang kelas ditata sesuai kebutuhan kelas sehingga kelas tidak penuh sesak sehingga suasana di kelas menjadi lebih bersih dan siswa merasa nyaman selama mengikuti pembelajaran. Daniel Muijs dan David Reynolds menyatakan salah satu prinsip umum adalah para siswa seharusnya memiliki ruang yang cukup untuk bekerja/melakukan kegiatan pembelajaran dengan nyaman oleh karena itu pengaturan tempat duduk dan ruang kelas berpengaruh terhadap kelancaran dan kenyamanan siswa dalam mengikuti pembelajaran(Muijs and Reynolds 2008)

Terjadinya perbedaan nilai rerata prestasi belajar IPS siswa disebabkan kelompok eksperimen yang diberikan perlakuan pengelolaan kelas secara fisik membuat siswa tertarik untuk belajar dengan suasana kelas yang nyaman dan menyenangkan serta ditunjang dengan media pembelajaran yang disesuaikan dengan materi yang disampaikan, sedangkan kelompok IVA yang diberi pengelolaan kelas berupa pengaturan siswa, para siswa cenderung lebih cepat bosan serta kurang memberikan perhatian terhadap materi yang disampaikan selama proses pembelajaran berlangsung. Hal ini dikarenakan penataan tempat duduk siswa yang tidak berubah, sehingga pandangan siswa selalu sama setiap harinya, tanpa merasakan mengikuti pembelajaran dengan pandangan dari posisi tempat duduk yang lain.

Seorang guru dituntut mampu memilih dan menggunakan media pembelajaran sesuai dengan materi yang akan disajikan. Di samping itu, guru juga dituntut mampu memilih metode pembelajaran yang sesuai dengan materi yang diajarkan untuk menghidupkan suasana pembelajaran yang nyaman dan aman serta menyenangkan. Dengan kata lain, dalam pelaksanaan pengelolaan kelas guru harus dapat menciptakan suasana yang memungkinkan seorang peserta didik memiliki kenyamanan dan rasa aman serta menyenangkan dalam proses 
pembelajaran. Hal ini dikarenakan beberapa hal yang disebutkan di atas termasuk dalam pengelolaan kelas secara fisik berupa pengaturan dan pemanfaatan media pembelajaran, serta pemilihan strategi pembelajaran.

Penekanan terhadap pengelolaan kelas berupa pengaturan siswa saja kurang dapat menghasilkan peserta didik seperti yang diharapkan. Suatu kondisi belajar yang optimal dapat tercapai apabila seorang guru mampu menciptakan siswa dan sarana pengajaran serta mengendalikannya dalam suasana yang menyenangkan. Proses menciptakan serta mengendalikan suasana pembelajaran yang menyenangkan yaitu dengan pengelolaan kelas yang efektif yaitu pengelolaan kelas secara fisik dan pengaturan siswa. Syaiful bahri Djamarah menyatakan pengelolaan kelas yang efektif merupakan prasyarat mutlak bagi terjadinya proses pembelajaran yang efektif. Oleh karena itu, pengelolaan kelas merupakan suatu hal penting guna terciptanya pembelajaran yang efektif agar tujuan pembelajaran tercapai dan berpengaruh terhadap prestasi belajar IPS siswa.

Berdasarkan hasil pembahasan di atas, maka dapat disimpulkan bahwa penerapan pengelolaan kelas yang efektif dan optimal, mampu menciptakan suasana pembelajaran yang nyaman dan menyenangkan selama proses pembelajaran berlangsung dan mampu menarik perhatian siswa untuk mengikuti proses pembelajaran dengan baik, dan berpengaruh terhadap prestasi belajar IPS siswa.

\section{PENUTUP}

Berdasarkan hasil penelitian dan pembahasan, maka dapat disimpulkan sebagai berikut: kelompok eksperimen yang diberi pengelolaan kelas secara fisik dan pengaturan siswa memperoleh nilai postest lebih baik dibandingkan dengan kelompok kontrol yang tidak diberikan pengelolaan kelas secara fisik dan pengaturan siswa. Hal ini ditunjukkan dengan perolehan nilai rerata kelompok eksperimen lebih baik dari kelompok kontrol yaitu terjadi peningkatan nilai dari nilai pretest sebesar 74,8 menjadi 82,7 (kenaikan sebesar 9,5\%) untuk kelas eksperimen. Sedangkan untuk kelas kontrol hanya terjadi kenaikan nilai pretest 71 menjadi 72,4 (Kenaikan hanya 1,4\%) untuk kelas kontrol sedangkan nilai N-Gain yang didapatkan kelompok eksperimen nilai sedang 42\% dan nilai rendah sebesar 57\% kelompok kontrol terdapat nilai sedang $23 \%$ dan nilai rendah $76 \%$.

Respon siswa kelas kontrol terhadap pengelolaan kelas secara fisik dan pengaturan siswa yaitu sebesar $76 \%$ setuju dan $24 \%$ tidak setuju. Respon siswa kelas eksperimen terhadap pengelolaan kelas secara fisik dan pengaturan siswa yaitu sebesar $86 \%$ setuju dan $14 \%$ tidak setuju.

Armanisah | Tengku Hafinda | Keterampilan Guru Mengelola Kelas: Upaya Untuk Meningkatkan Prestasi Belajar Siswa | 180 
Berdasarkan hasil penelitian dan pembahasan di atas, maka dapat diajukan saran sebagai berikut: Para guru di sekolah diharapkan dapat merancang dan melaksanakan suatu kegiatan belajar yang dapat menciptakan suasana kondusif, yang dapat memberikan motivasi belajar siswa khususnya pada mata pelajaran IPS materi perkembangan teknologi produksi, komunikasi dan transportasi. Suasana kondusif dapat diaplikasikan melalui penataan ruangan yang mencerminkan kesejukan, ventilasi yang baik sehingga sirkulasi udara berjalan dengan baik, penataan atau kreativitas siswa dengan demikian siswa merasa memiliki atas segala perlengkapan maupun hiasan kelas. Diharapkan guru di sekolah memaksimalkan pengelolaan kelas secara fisik dengan penggunaan alat peraga yang dimiliki, hal ini ditujukan untuk memaksimalkan daya tangkap siswa terhadap suatu materi pembelajaran yang disampaikan dan pengelolaan kelas berupa pengaturan siswa dengan tindakan preventif dan tindakan korektif.

\section{DAFTAR PUSTAKA}

Arikunto, Suharsimi. 2007. Prosedur Penelitian Suatu Pendekatan Praktik. Jakarta: Rineka Cipta.

Creswell. 2003. Pendekatan Kualitatif, Kuantitatif, Dan Mixed.

Djamarah, Syaiful Bahri. 2002. Konsep Dan Makna Pembelajaran. Jakarta: Prenada Media Grup.

Entang, and Raka Joni. 2001. Strategi Belajar Mengajar. Bandung: pustaka setia.

Hizam, Ibnu. 2015. "EVALUASI PROGRAM PENYELENGGARAAN MTsN KEDIRI MODEL CIPP.” Jurusan Pendidikan IPS Ekonomi (xiv):22-42.

Kadir, St. Fatimah. 2006. “Keterampilan Mengelola Kelas.” Jurnal Al-Ta’dib 7(1).

Muijs, Daniel, and David Reynolds. 2008. Effective Teaching. Yogyakarta: Pustaka Pelajar.

Pratiwi, Ghany Mu'thi. 2018. "Pengaruh Keterampilan Guru Dalam Mengelola Kelas Terhadap Prestasi Belajar Siswa." Universitas Lampung.

S. Eko Putro Widoyoko. 2008. "Model Evaluasi Program Pembelajaran IPS Di SMP.” Jurnal Nasional XI:1-15.

Sapriya. 2009. Pendidikan IPS. Bandung: Remaja Rosdkarya.

Semiawan, Conny., Dkk. 1992. Pendekatan Keterampilan. Jakarta: Grasindo.

Solihatin, Etin. 2009. Pengaruh Kooperatif Learning Terhadap Belajar IPS Tinjau Dari Gaya Belajar. Jakarta: Bumi Aksara.

Armanisah | Tengku Hafinda | Keterampilan Guru Mengelola Kelas: Upaya Untuk Meningkatkan Prestasi Belajar Siswa | 181 
Sugiyono. 2011. Metode Penelitian Kuantitatif Kualitatif. Bandung: Alfabeta.

Usman, Husaini, and purnomo setyadi Akbar. 2011. Pengantar Statistika. Jakarta: Bumi Aksara.

Wiryawan, Sri Anitah, and Noorhadi. 2001. Strategi Mengajar. Jakarta: Universitas Terbuka. 